\title{
How Youth May Find Jobs: The Role of Positivity, Perceived Employability, and Support from Employment Agencies
}

\author{
Chiara Consiglio ${ }^{*}{ }^{\dagger}$, Pietro Menatta ${ }^{\dagger}$, Laura Borgogni, Guido Alessandri $\mathbb{D}^{\text {, }}$, Lucia Valente \\ and Gian Vittorio Caprara
}

check for updates

Citation: Consiglio, C.; Menatta, P.; Borgogni, L.; Alessandri, G.; Valente, L.; Caprara, G.V. How Youth May Find Jobs: The Role of Positivity, Perceived Employability, and Support from Employment Agencies. Sustainability 2021, 13, 9468. https:// doi.org/10.3390/su13169468

Academic Editors: Amelia Manuti and Maria Luisa Giancaspro

Received: 7 July 2021

Accepted: 20 August 2021

Published: 23 August 2021

Publisher's Note: MDPI stays neutral with regard to jurisdictional claims in published maps and institutional affiliations.

Copyright: (C) 2021 by the authors Licensee MDPI, Basel, Switzerland. This article is an open access article distributed under the terms and conditions of the Creative Commons Attribution (CC BY) license (https:// creativecommons.org/licenses/by/ $4.0 /)$.
Department of Psychology, Sapienza University of Rome, 00185 Rome, Italy; pietro.menatta@gmail.com (P.M.); laura.borgogni@uniroma1.it (L.B.); guido.alessandri@uniroma1.it (G.A.); lucia.valente@uniroma1.it (L.V.); gianvittorio.caprara@uniroma1.it (G.V.C.)

* Correspondence: chiara.consiglio@uniroma1.it

+ Chiara Consiglio and Pietro Menatta contributed equally to this work.

\begin{abstract}
Youth unemployment is a relevant issue among most European countries; therefore, it is important to understand its individual and situational determinants. This study aimed to investigate a conceptual model that explains the associations among positivity (POS), perceived support from employment agencies, perceived employability (PE), and employment status in a sample of 317 unemployed Italian youth involved in the Youth Guarantee program. In particular, this study investigated the relationships between POS and PE and between PE and employment. Moreover, we analyzed whether the relationship between POS and employment status was mediated by PE and whether the relationship between POS and PE was moderated by perceived support from employment agencies. Results showed that PE totally mediated the relationship between POS and employment status. Furthermore, the moderating role of perceived support from agencies was confirmed; when high, it boosted the relationship between POS and PE. In sum, this study contributes to understanding the key impact of POS on PE, as well as the role played by employment agencies as a "catalyst" of this relationship, allowing, with their support, unemployed youth to maximize their opportunity to find a job. Implications for both research and practice are discussed.
\end{abstract}

Keywords: perceived employability; positivity; personal resources; youth unemployment; support from employment agency; employment; Youth Guarantee program

\section{Introduction}

Youth unemployment has been a key concern for governments, educational systems and society as a whole, especially in the aftermath of the Great Recession of 2008-2013 [1]. It is a matter of fact that youth employment suffers during periods of economic recession [2] much more than adult employment [3-5]. Among unemployed youths, those who have attracted the greatest concerns from the European governmental and educational institutions are those included in the general label "NEET" (Not in Employment, Education, or Training) [6,7]. Growing up in disadvantaged circumstances (e.g., early dropout from initial education) and lacking support, NEETs stand at higher risk of social exclusion, unemployment, or precarious work arrangements [8,9]. Therefore, it has become a focal point to understand determinants of their employability so as to avoid the prospect of dealing with a so-called "lost generation" [10,11].

This goal is in line with sustainable development goals, which comprise reducing poverty and social exclusion and promoting decent work and wellbeing [12]. The new transdisciplinary field of psychology of sustainability and sustainable development [12-14] aims at improving the quality of life of human beings within different (ecological, economic, social, and working) environments $[13,14]$. This new psychological perspective is in line with the positive psychological approach, which focuses on the promotion of resources, growth, and quality of life [12-14]. Following this view, our study investigated 
the subjective and social resources that may enable young unemployed people to maximize their opportunities to develop their employability and enter the labor market.

Adopting a psychological and subjective approach [15], this study aimed at understanding determinants of perceived employability (PE, defined as the individual's perception concerning their own possibilities of gaining new employment [16]) in a sample of NEETs that took part in the Youth Guarantee program (transl. Garanzia Giovani), a European program aimed at reducing youth unemployment using a combination of contextualized supportive measures (the goals and modalities of the program are described more in detail in Section 1.4). Since PE is defined as a subjective perception, understanding its determinants is crucial given that individuals act based on their subjective perceptions of themselves and of reality [17]. Moreover, PE is of the utmost importance for the unemployed, given that perceiving employment opportunities in the labor market increases their feelings of control over their careers [18], increases job search activities [19,20], decreases the length of unemployment [21], and ultimately facilitates re-employment [22]. Though some previous research has related dimensions such as self-esteem, optimism, and life satisfaction to PE [23-27], to our knowledge, none have related positivity to PE in a sample of NEETs. Therefore, our first aim was to investigate positivity (POS, defined as a positive stance towards life and experience), which represents the common root of self-esteem, life satisfaction, and optimism [28-30] and serves as a basic evaluative disposition, and its potential association with PE. Based on the Conservation of Resources (COR) model [31,32], POS may represent a basic dispositional resource in dealing with stressful and challenging circumstances, since a positive orientation toward the world leads people to understand events as predictable and generally occurring in their favor [31]. Moreover, POS has been previously linked to several positive outcomes pertaining to the work domain such as job performance, work engagement and organizational citizenship behavior [30]. Referring to the POS literature, to date, POS has not been measured in a sample of NEETs in search of their first employment nor has POS been studied in relation to PE.

Another aim of this study was to investigate the role of contextual support received at the local level, its interplay with POS, and its relationship with PE. In so doing, we conceived perceived support from agencies that assist NEETs during the Youth Guarantee program as a perceived contextual factor. Within this program, employment agencies play an important role in profiling, training, and gaining access to local employment opportunities. We argue that support from agencies interacts with POS in a way that would help NEETs translate their positivity into high perceived possibilities of getting a job.

Moreover, to the best of our knowledge, PE has never been studied in relation to getting employment among NEETs approaching the first phases of exploration of the labor market. Rothwell, Jewell, and Hardie [33] also noticed the lack of research on PE in relation to postgraduates compared to that in relation to graduate students. Hence, we aimed to extend evidence from the unemployed by investigating the relationship between PE and employment status in this specific sample and examine whether PE could be conceived as the work-facet consequence of POS, through which positivity would relate with actual employment status.

In sum, this study investigated, in a sample of Italian NEETs involved in the Youth Guarantee program: (a) the relationship between POS and PE, (b) the relationship between $\mathrm{PE}$ and employment status, (c) the total mediation of PE in the relationship between POS and employment status, and (d) the moderation of perceived support from agencies in the relationship between POS and PE.

\subsection{Perceived Employability and Its Relationship with Positivity}

The concept of employability was originally associated with a governmental and educational duty that required policies aimed to achieve full employment, especially for those excluded by the labor market [34-37]. More recently, research has moved toward a renewed approach to employability that focuses on individuals' subjective experience, namely their views, perceptions, and anticipations about work and employment [38]. 
Within this perspective, employability has been alternatively viewed as a multidimensional trait $[25,27,39]$, a personal resource [40] resulting from a specific pool of competencies [41,42] and metacompetencies [43], and a subjective perception [16,23,24,44]. This heterogeneity of conceptualizations led to making employability, at first glance, a "fuzzy notion" [35,45].

Adopting the individual perspective, Vanhercke and colleagues [15] proposed an integration of the dispositional approach [39] and competency-based approach [41] to employability, creating a process model of perceived employability (PE) $[16,46,47]$. In their view, abilities (competency-based approach) and motivational attitudes (dispositional approach) are related to each other and result in PE, namely the "individual's perception of his or her possibilities of getting new employment" [16] (p. 281). Vanhercke and colleagues [15] also accounted for context as a moderator of the relationship between competencies/attitudes and PE. Finally, they hypothesized a feedback loop by which PE in turn stimulates motivational attitudes and skill development. As such, PE reflects the result of the interaction between personal and contextual factors [37,46,48,49]. We adopted this framework, and we investigated PE because it provides an overall subjective evaluation of possibilities for employment $[15,16]$. Furthermore, PE has already been studied in samples of graduate students in the exploration stage of their first employment $[33,36]$ as well as in samples of unemployed individuals [50,51]. Of importance is the nature of the PE dimension. Being a subjective perception, PE concerns an individual's beliefs that affect behaviors, feelings, and thoughts more than objective reality itself does [52]. The drawback is that it "does not provide information about why individuals perceive themselves as highly or less employable" [15] (p. 599); hence, it is crucial to identify PE determinants [53]. Accordingly, several studies have investigated specific personal dispositions and resources that may enhance PE over and beyond the effect of demographic characteristics, as well as competency-based and dispositional employability [54]. Among these, self-esteem [27], optimism [25,26], and life satisfaction [24] have been positively related to PE. More recently, core-self evaluations (which comprised self-esteem, generalized self-efficacy, neuroticism, and locus of control) were also associated to perceived employability [55]. We integrated these findings by adopting a multifaceted approach to the study of the cognitive component of well-being, namely "positive orientation" or "positivity" (POS) [28,29]. POS may be traced to a common latent construct, including self-esteem (the degree of global regard and acceptance that an individual has for themselves as a person) [56], optimism (the general tendency to believe in good instead of bad outcomes) [57-59], and life satisfaction (a subjective evaluation that summarizes the degree of gratification one has ultimately had in their life) [60]. POS refers to "a basic evaluative predisposition that exerts an important biological function in enabling people to grow, to flourish, and to consider life worth living" [30] (p. 670). Caprara and colleagues [29] demonstrated evidence of POS's hereditability, cross-cultural generalizability, and stability over time. Moreover, this positive attitude towards life and experience affects how individuals predispose themselves to actions in various life domains, including the work setting. Alessandri and colleagues [30] showed that POS contributes to enhanced supervisory ratings and objective measures of job performance and organizational citizenship behavior (OCB) [61] over and above both its first-order component and the contribution of other well-established individual differences including Big Five personality traits [62], Positive Affectivity [63], and Core Self-Evaluations [64]. Alessandri, Borgogni, Schaufeli, Caprara, and Consiglio [65] also showed that work engagement [66] partially mediated the relationship between POS and job performance as assessed by multiple supervisors. Furthermore, Laguna, Alessandri, and Caprara [67] studied personal goal realization in entrepreneurs and reported that positive goal-related affect and POS were positively related. Although POS has been the subject of a wealth of study, few studies have been conducted in the work domain, and the only empirical evidence on POS applied in the context of unemployment comes from the study of Theodorou, Violani, and Alessandri [68]. The authors investigated, in a sample of unemployed individuals, the role of POS in the promotion of mental and physical health 
through the reduction of perceived economic stress and the adoption of health-relevant behaviors. POS was positively associated with mental health through both mediators. Therefore, among the unemployed, POS was associated with well-being indicators, but not with occupational outcomes.

In line with the idea that PE derives from both personal and contextual factors [15,37], we considered POS a personal factor related to PE. POS represents a metatrait representing what is common to self-esteem, life satisfaction, and optimism [29], and several studies have shown that POS provides a broader explanatory contribution than its single lower-order components [30] to important working outcomes [30,69]. Since POS is depicted as a basic disposition, it provides a pervasive mode of appraising events and predisposes individuals to action and experiences [29]. In accordance with the Conservation of Resources Model (COR) [31,32], this positive stance towards reality might represent a key personal resource able to buffer the negative effects of stressors and maximize the benefits of the positive sides of work [31,70].

On the other hand, as perceived employability involves the subjective interpretation of one's abilities to find a job, it is likely to be affected by basic individual attitudes [19]. Hence, a positive view of oneself, one's life, and one's future should positively color individuals' perceptions regarding the labor market, their own skills, and work success, thereby enhancing their PE. Accordingly, we hypothesized that POS is a resourceful personal factor that predisposes youth in search of employment to believe they have a chance of getting a job. Hence, our first hypothesis was as follows:

H1. POS positively relates to PE.

\subsection{From Perceived Employability to Employment Status}

There is a wealth of evidence concerning the beneficial effect generally played by $\mathrm{PE}$ in terms of enhanced health, well-being [16,71], engagement, and life satisfaction [21] and reduced burnout and related psychological symptoms $[48,72,73]$. Other studies have associated PE to different indicators of career success [74] and positive occupational outcomes such as job search behaviors and job satisfaction [27,41]. However, few studies have considered objective or external indicators (such as income, career advancements, or supervisor performance evaluations) [40]. With regard to the specific target of this study, namely youths looking for a job, employability was originally acknowledged as an important dimension to make the labor market more inclusive for vulnerable groups (e.g., school leavers and the unemployed) [75]. It is well-known that employability is remarkably relevant during transitions such as re-employment and in the first phases of exploration of the labor market [76]. Regarding the former, employability has been conceived as the determinant of achieving re-employment [77]. For instance, Brouwer, Bakker, and Schellekens [22] showed that positive expectations about returning to work contributed to reemployment, while Knabe and Rätzel [21] highlighted a negative relationship between perception of the ease of obtaining a new job and the effective length of unemployment. $\mathrm{PE}$ among the unemployed has been further investigated in relation to job search activities [19,20]. Chen and Lim [19] showed that PE affected two types of job search behaviors (preparatory and active) through the mediation of problem-focused coping. De Battisti and colleagues [20] found that PE was positively related to focused job search strategies, and these strategies increased the likelihood of re-employment. Moreover, McArdle and colleagues [27] investigated dispositional employability (comprising adaptability, career identity, and human and social capital) as conceived by Fugate and colleagues [25]) in a sample of unemployed individuals. The authors showed that employability was positively related to the intensity of job-seeking behaviors and positively affected re-employment at a 6-month follow-up.

Furthermore, we have already noted that re-employment and length of unemployment were, respectively, positively and negatively related to PE [21,22]. This reflects the general idea that subjective perceptions drive behavior [52]. The link between PE and actual 
occupational status stems from the perception of control over one's career that is increased by $\mathrm{PE}$ and allows individuals to identify employment opportunities in the labor market [18]. Thereby, "individuals first appraise potential employment opportunities and then act upon the opportunities they perceive" [75] (p. 59). In this fashion, PE stands out as a resource during unemployment that enhances feelings of control and viability of job opportunities, which, in turn, activates individuals and ultimately reduces the negative effects of unemployment $[20,78]$. Accordingly, we assume that youths who believed in their capability to get a new job would capitalize from the Youth Guarantee and from the activities (e.g..., traineeship) proposed within this project by achieving new employment. Conversely, NEETs who believed they had few or no chances of getting a job would not have confidence in their own capabilities and would not place credibility in the proposed activities as a way to obtain a new job. Accordingly, we examined the following hypothesis:

H2. PE positively relates to employment status after the Youth Guarantee program.

\subsection{From Positivity to Employment Status: The Mediational Role of Perceived Employability}

Moving over and beyond the relationship between POS and PE, POS has proven to affect the work domain by enhancing, for instance, job performance and OCB $[30,65]$. Similarly, this positive stance towards life and experience may exert a positive effect on getting a job by enhancing the possibilities that youth believe they have in achieving their first employment; essentially, those with greater resources will be more capable of resource gain $[79,80]$. Since PE is susceptible to basic positive attitudes [19], it might represent the way through which POS affects individuals' subjective appraisal and translates into action their beliefs on possibilities of employment. In sum, individuals appraise themselves and the labor market through the lens of POS, which influences their perception about their possibilities of getting a new job. This perception could actually help in identifying potential employment opportunities and allows individuals to act upon the opportunities they perceive. Hence, our third hypothesis is the following:

H3. PE mediates the relationship between POS and employment status after the Youth Guarantee program.

\subsection{The Moderating Role of Agency Support in the Relationship between Positivity and Perceived Employability}

The Youth Guarantee program is an active labor market policy measure that started from a proposal advanced by the European Commission in April 2013. This initiative committed all the member states to fostering "a situation in which young people receive a good-quality offer of employment, continued education, an apprenticeship, or a traineeship within a period of four months of becoming unemployed or leaving formal education" [81] (p. 1). The EU particularly supported those nations with youth unemployment rates above $25 \%$ in developing their national Youth Guarantee Implementation Plan [6]. In Italy, a country with one of the highest youth unemployment rates (about 30\% at the end of 2020 [82]), NEETs between 15 and 29 years of age were called to participate in the Youth Guarantee program. Financial support was provided by the European Social Fund and the Youth Employment Initiative, while the responsibility for the implementation and provision of services related to the project was delegated by the country to the individual regions. To carry out the activities envisioned by the program, regions refer to both public employment offices and private employment agencies. Specifically, employment offices are responsible for taking charge, for the onboarding of participants, and for providing them with initial guidance. On the other hand, employment agencies, previously accredited to the regional systems, are responsible for supporting participants to actually get a job. They provide youth with targeted education and training, carry out scouting for job offers, and take care to maximize their chances of employment. In doing so, agencies deploy qualified personnel and earned a fee based on actual hiring. Therefore, agencies are more closely involved with job seeking, and the effectiveness of the activities proposed under the program would primarily owe to their efforts. Since agencies were identified as the 
most relevant contextual counterpart to support youth in getting a job, this study focused on the support provided by the agencies within the Youth Guarantee program as perceived by program participants.

Referring to the effect provided by public policy, few scholars have focused on higher education and its ability to enhance graduates' employability by offering dedicated programs or internships $[83,84]$. Other scholars have investigated employment agency activities and effectiveness in increasing the chances of the re-employment of their unemployed clients $[20,85]$. Research in private contexts has shown that organizational support for career and skill development positively affected PE [53]. In a similar manner, we assume that agencies may enhance youths' PE by providing all of the information they require, by helping them to get good profiling and matching for traineeships, and by providing them assistance when required throughout the program. As is already well known, the presence of this social support may lead individuals to view the job search as a worthwhile activity [77]. According to the well-established idea that personal and contextual factors interact in enhancing PE [15], we assume that being highly supported by the agency may represent a perceived contextual resource that plays a role alongside POS (personal factor), interacting in a way to enhance youth's PE. Therefore, in line with the COR Model, which posits that individual and contextual resources are not isolated but travel in resource caravans $[79,80]$, the support provided by the agency may reinforce and amplify the positive stance toward reality by helping to translate POS into a perception of higher possibilities to getting a job. In particular, positive young people may benefit from the support they receive in their job search, as the work opportunities that agencies offer them become a reliable anchor from which they derive a positive perception of their employability. In contrast, youth who do not receive support from the agencies may receive fewer opportunities that likely may not fit with their qualifications, competencies, and career goals. Hence, when agencies fail in providing guidance and profitable employment opportunities, youth may find it hard to channel their general POS towards the work setting by enhancing PE. Accordingly, we examined the following hypothesis:

H4. Perceived support provided by the employment agency will moderate the relationship between POS and PE, so that the relationship will be more positive at higher levels of perceived agency support.

The overall conceptual model is presented in Figure 1.

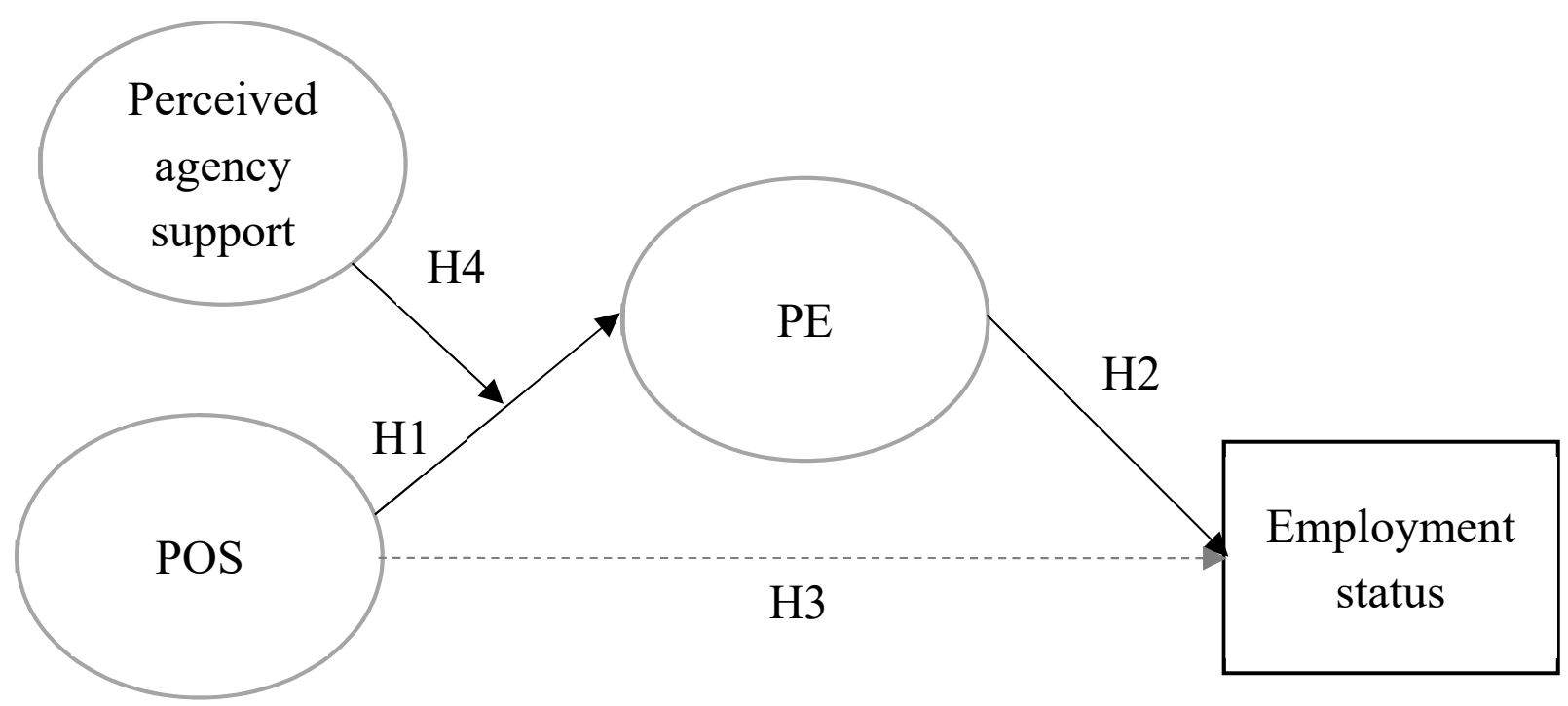

Figure 1. The overall conceptual model. Note: POS = Positivity; PE = Perceived employability. 


\section{Materials and Methods}

\subsection{Sample and Procedure}

Data for this study were drawn from a larger research project aimed at investigating the process of job searching and the resulting employment outcomes of Italian youth. Participants were reached thanks to collaboration with the Lazio Region Department of Labor, which is the local referent of the Youth Guarantee program. Lazio Region's representatives provided the research team with a list of 6000 email addresses of youth who were involved in and completed the Youth Guarantee program in 2017. Youth were invited to fill in an online questionnaire attached to an e-mail explaining the aims of the research and how to take part in it. Participation in the study was voluntary, and the research team guaranteed confidentiality to all respondents. The final sample comprised 317 Italian NEETs who were involved in and completed the Youth Guarantee program. Fifty-nine percent were female, and the mean age was 26.65 (SD = 2.57). Regarding education, $38.8 \%$ declared a bachelor's degree, $51.6 \%$ had a high school certificate, $5 \%$ completed a technical college, and $4.6 \%$ attended only junior high school. Furthermore, $72.9 \%$ had already worked for a period before the Youth Guarantee program, and among those, $54.3 \%$ had previously worked as employees, $28.3 \%$ as trainees, $5.2 \%$ as self-employed, and $12.2 \%$ reported previous involvement in other occasional work activities. Moreover, $63.4 \%$ declared having been employed after participating in the program.

\subsection{Measures}

\subsubsection{Positivity}

We measured POS by using the P-Scale [69], which comprises eight items (e.g., "I feel I have many things to be proud of"). One of the items was negatively worded ("At times, the future seems unclear to $\mathrm{me}^{\prime \prime}$ ) and thus was reverse scored. Participants were asked to answer items using a 7-point Likert scale ranging from 1 (strongly disagree) to 7 (strongly agree). The coefficient alpha reliability was 0.83 .

\subsubsection{Perceived Employability}

Perceived employability was assessed by using four items adapted from the measure introduced by Berntson and Marklund [16] (e.g., "My competence is sought-after in the labor market"). Participants rated their agreement on a 7-point Likert scale ranging from 1 (strongly disagree) to 7 (strongly agree). The coefficient alpha reliability was 0.78 .

\subsubsection{Perceived Support from Employment Agency}

Perceived employment agency support was assessed using a tailor-made scale comprising the following four items: (1) "the employment agencies, during the Youth Guarantee program, provided me with all the needed information"; (2) "the employment agencies provided me with support during the Youth Guarantee program in case of difficulties along the way"; (3) "the employment agencies shared an individualized placement plan with me during the Youth Guarantee project"; and (4) "the employment agencies, during the Youth Guarantee project, have facilitated the development of my professional skills". Participants answered using a 7-point Likert scale ranging from 1 (strongly disagree) to 7 (strongly agree). The coefficient alpha reliability was 0.94 .

\subsubsection{Employment Status}

Employment status was assessed using a single question measuring a dichotomous variable (employed $=1$, unemployed $=0$ ).

\subsection{Modeling Strategies}

We tested a moderated mediation model in which (a) PE mediated the relationship between POS and employment status and (b) perceived support from employment agencies moderated the effect of POS on PE. The significance of the indirect effect of POS on employment status was investigated by estimating the associated $95 \%$ confidence intervals 
in using the RMediation package in R [86]. The significance of the moderated effect of perceived support by employment agencies was tested by investigating the significance of the cross-product term representing the interaction between POS on PE. To do so, we centered first-order terms around the sample's grand mean before computing the cross-product interaction terms so as to eliminate nonessential multicollinearity and allow their interpretation [87]. Simple slope analysis was used to investigate changes in the relationship between POS and PE at both high (1 SD above the mean) and low (1 SD below the mean) levels of perceived support by employment agencies. Furthermore, both age and education were included as control variables, as they were significantly correlated with the study variables, in accordance with previous studies $[53,88]$. However, once tested, nonsignificant effects of covariates were fixed to zero.

Finally, to provide further evidence of the appropriateness of the hypothesized model, we investigated other two plausible alternative models. In the first model, we tested whether POS directly related to employment status, which would support a partial, rather than a total, mediation of PE. In the second model, we removed the cross-product term between POS and perceived support from employment agencies.

\subsection{Statistical Analysis}

The distinctiveness of POS, perceived support from the employment agency, and PE was investigated in preliminary analyses by running a confirmatory factor analysis (CFA) using the maximum likelihood (ML) estimator in Mplus 8.2 [89]. In detail, a three-factor model was tested against (1) three possible solutions with two latent factors and (2) a onefactor solution. Following this, the main hypotheses were tested via path analysis within the structural equation modeling (SEM) framework. Given that employment status was a dichotomous non-normal dependent variable, the hypothesized moderated mediational model was tested using the robust weighted least squares (WLSMV, see [90]) method, which is well-suited for models with categorical variables [91,92]. The WLSMV estimator provides weighted least squares parameter estimates using a diagonal weight matrix and robust standards errors as well as both mean and variance-adjusted chi-square test statistics [93]. Model fit was evaluated by looking at the values of the comparative fit index (CFI), the Tucker-Lewis Index (TLI), the root mean square error of approximation (RMSEA), and the standardized root-mean-square residual (SRMR). Good models were those with: (1) values of CFI and TLI higher than 0.90 [94], (2) RMSEA values of 0.08 or less [95], and (3) SRMR less than 0.05 [96].

Nested models were compared by using the DIFFTEST option in Mplus, which allows for models' comparison using the WLSMV estimator. Non-nested models were instead compared by comparing the associated values assumed by an adapted version of the AIC for the WLSMV estimator see [97], using the following formula [98]: $\triangle \mathrm{AIC}=\mathrm{AICi}-\mathrm{AICmin}$, where AICmin is the minimum observed AIC between the two models. Burnham and Anderson [99] suggested that $\triangle \mathrm{AIC}<2$ means that the models have comparable fit. $\triangle \mathrm{AIC}$ values between 4 and 7 are considered as providing less support, whereas $\triangle \mathrm{AIC}>10$ means that the best-fitting model should be considered instead of the competitive one.

\section{Results}

Descriptive statistics and correlations among POS, perceived support from employment agencies, PE, employment status, age, and education are listed in Table 1. All the study variables were positively and significantly correlated.

\subsection{Confirmatory Factor Analysis}

As in previous studies [69], all models were estimated by allowing a correlation between uniqueness of two of POS items ("I have great faith in the future" and "I look forward to the future with hope and enthusiasm"). As shown in Table 2, the hypothesized model showed good fit indices and fitted the data better than any alternative model considered. 
Table 1. Descriptive statistics and correlations.

\begin{tabular}{|c|c|c|c|c|c|c|c|c|}
\hline & $M$ & $S D$ & 1 & 2 & 3 & 4 & 5 & 6 \\
\hline 1. POS & 4.70 & 1.20 & $(0.83)$ & & & & & \\
\hline $\begin{array}{l}\text { 2. Perceived } \\
\text { agency support }\end{array}$ & 3.55 & 1.94 & $0.19^{* *}$ & $(0.94)$ & & & & \\
\hline 3. PE & 4.40 & 1.35 & $0.49^{* *}$ & $0.17^{* *}$ & $(0.78)$ & & & \\
\hline $\begin{array}{l}\text { 4. Employment } \\
\text { status }\end{array}$ & 0.63 & 0.48 & 0.10 & 0.14 * & $0.19 * *$ & & & \\
\hline 5. Age & 26.65 & 2.57 & $-0.13^{*}$ & $-0.13 *$ & 0.10 & 0.05 & - & \\
\hline 6. Education & 0.39 & 0.49 & -0.01 & -0.04 & $0.19^{* *}$ & $0.19 * *$ & $0.49 * *$ & - \\
\hline
\end{tabular}

Note: ${ }^{*} p<0.05 ; * *<<0.01(\mathrm{~N}=317) ; \mathrm{POS}=$ Positivity; PE = perceived employability; coefficient alpha reliability estimates are presented in brackets along the diagonal.

Table 2. Results of confirmatory factor analyses.

\begin{tabular}{cccccccc}
\hline Models & $\boldsymbol{\chi} \mathbf{2}$ & $\boldsymbol{\Delta} \mathbf{\chi 2}^{2}$ & $\mathbf{d f}$ & $\mathbf{\Delta d f}$ & $\mathbf{C F I}$ & $\mathbf{R M S E A}$ & SRMR \\
\hline 3-factor model & 325.75 & & 100 & & 0.93 & 0.08 & 0.07 \\
2-factor model a & 602.59 & $276.84^{* * *}$ & 102 & 2 & 0.84 & 0.12 & 0.08 \\
2-factor model b & 850.03 & $524.28^{* * *}$ & 102 & 2 & 0.76 & 0.15 & 0.17 \\
2-factor model c & 1652.42 & $1326.67^{* * *}$ & 102 & 2 & 0.49 & 0.22 & 0.16 \\
1-factor model & 1751.17 & $1425.42^{* * *}$ & 103 & 3 & 0.46 & 0.23 & 0.17 \\
\hline
\end{tabular}

Note: ${ }^{* * *} p<0.001$; 2-factor model $\mathrm{a}=\mathrm{PE}$ and POS items in a single factor; 2-factor model $\mathrm{b}=\mathrm{PE}$ and perceived agency support items in a single factor; 2-factor model c $=$ POS and perceived agency support items in a single factor.

\subsection{Moderated-Mediation Model}

The hypothesized model showed a good fit to the data: CFI $=0.99, \mathrm{TLI}=0.96$, RMSEA $=0.038,95 \%$ CI $(0.000,0.109)$, SRMR $=0.041$ (Figure 2). Shows a graphical representation of the model and the associated parameter estimates. As hypothesized, POS was positively related to $\mathrm{PE}(\mathrm{H} 1)$, and $\mathrm{PE}$ was positively related to employment status (H2). Also, the indirect effect of POS on employment status (H3) was statistically significant $(0.08, p 0.013,95 \% \mathrm{CI}=0.02,0.14)$. Importantly, the cross-product term between POS and perceived support from employment agencies was significant. The model explained $31.9 \%$ of the variance in PE and $9.6 \%$ of the variance in employment status.

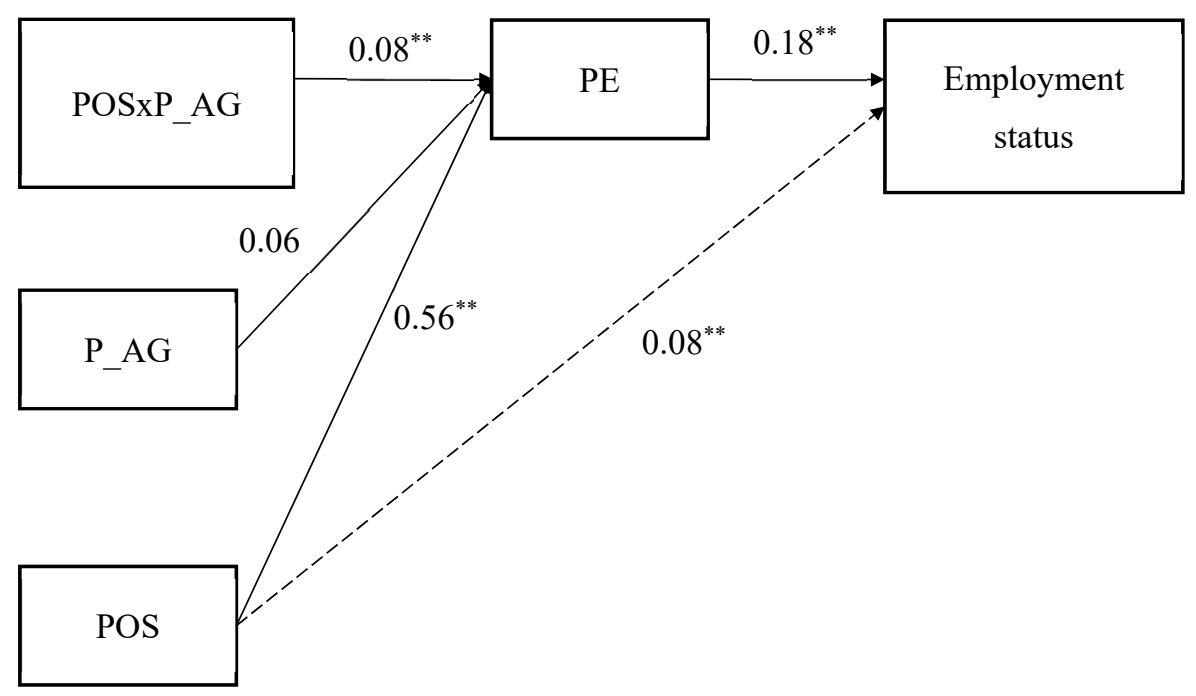

Figure 2. Parameter estimates of the path analysis model. Note: ${ }^{*} p<0.05 ;{ }^{* *} p<0.01$; POSxP_AG $=$ cross-product term between POS and perceived support from employment agency; P_AG = perceived support from employment agencies; POS = positivity; $\mathrm{PE}$ = perceived employability; solid lines are used to represent hypothesized direct effects, while broken lines are used to represent the hypothesized indirect (mediated) effect of POS on perceived support from employment agencies; coefficients within the dashed square were non-standardized, while that between PE and employment status was standardized. 
Simple slope analysis (Figure 3) showed that the relationship between POS and PE was significant at both high and low levels of employment agency perceived support. However, at higher levels of perceived support, the slope describing the relationship between POS and PE was larger $(\mathrm{B}=0.10, p=0.01)$ in comparison to the slope for lower levels of perceived support $(\mathrm{B}=0.06, p=0.02)$. Therefore, the relationship between POS and $\mathrm{PE}$ was stronger for young people perceiving higher levels of perceived support from employment agencies (H4).

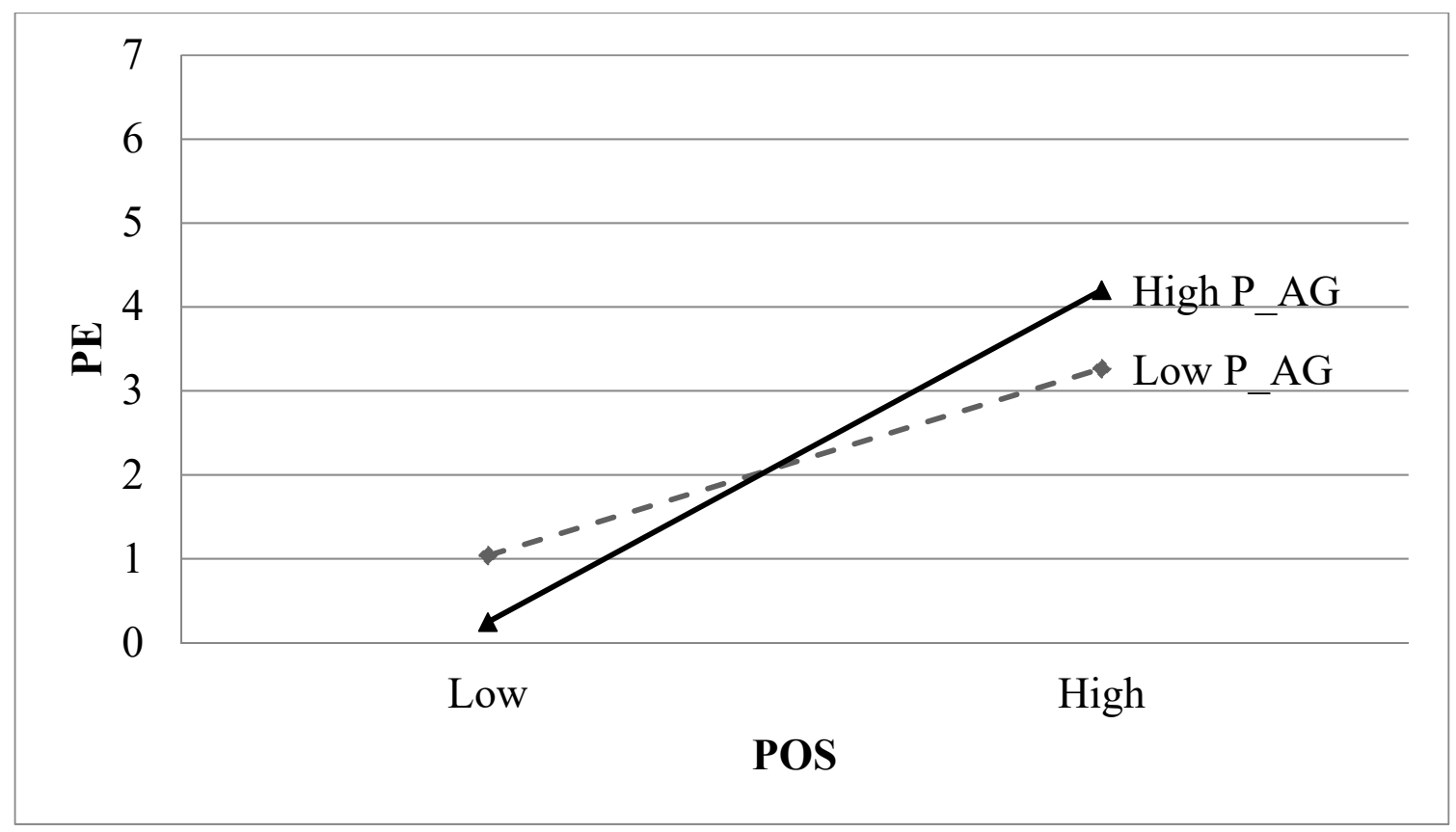

Figure 3. Graphical representation of the conditional effect of POS on PE depending on high and low levels of perceived support from employment agencies.

\subsection{Alternative Models}

The first alternative model added the direct relationship between POS and employment status, involving a partial, rather than a total, mediation of PE. This model showed a good fit to the data (CFI $=0.98, \mathrm{TLI}=0.89, \mathrm{RMSEA}=0.061,95 \% \mathrm{CI}(0.040,0.131)$, SRMR $=0.04)$. However, the diff-test function $\left.\Delta \chi^{2}(1)=0.01, p=0.91\right)$ suggested that the hypothesized total-mediated model was far better than this model. Furthermore, the direct effect was not significant $(p=0.91)$, providing further evidence of the total mediation of PE on the relationship between POS and employment status.

The second alternative model, which did not include the interaction term between POS and perceived support from employment agencies, fit the data reasonably well (CFI $=0.98$, TLI $=0.90$, RMSEA $=0.061,95 \%$ CI $(0.000,0.141)$, SRMR $=0.043)$. However, this model resulted in a slightly higher AIC than the hypothesized model, even though the difference between the indices of the two models was substantially negligible $(\triangle \mathrm{AIC}=0.44)$. Therefore, since these two models performed comparably well, the hypothesized model was preferred.

\section{Discussion}

The general purpose of this study was to investigate POS and the perceived support provided by employment agencies as antecedents of PE as well as the relationship of PE with youths' employment status after being involved in the Youth Guarantee program. All in all, the results derived from path analysis supported our hypotheses.

First, we contributed to extending the literature by demonstrating a significant and positive relationship between POS and PE. This finding corroborates the idea that looking at the world with a positive stance protects individuals from negative perceptions derived 
from stressful events, such as approaching new work situations and challenges. According to the COR model [31,32], a positive orientation represents a resource that enables individuals to perceive events as opportunities rather than obstacles. As such, POS provides a positive psychological state that influences perceptions [19], allowing youth to believe in their capability to properly engage in the work environment in order to get a job. In particular, considering the single components of POS, optimism, being a positive outcome expectancy, can make the difference between giving in to difficulties or persevering with one's own goals $[57,58]$. In addition, a positive consideration of oneself (self-esteem) protects individuals from the negative condition of being unemployed [99], helps to define a clear idea of their career [25,26], and ultimately enhances job search activities [77]. Furthermore, life satisfaction not only implies a subjective appraisal but also reflects objective conditions (e.g., past work experience, social support) across different domains [100] that equip people to face challenges with the memory of objectively positive events in their past [101]. Hence, the joint effect of these components led POS to represent a source of confidence for youth approaching the work world, associated with a rosy perception of their PE. According to the COR Model, resource gain becomes more salient in the context of resource loss, as in the case of unemployment $[31,80]$.

Second, PE was significantly and positively associated to actual employment status. In other words, youth perceiving themselves as having great possibilities of getting a job, actually got one. Youth that feel highly employable have greater control over their careers [18], and this reflects in them considering themselves able to engage in more jobs as well as in qualitatively different ones [102]. This result corroborated existing literature that has shown that PE effectively leads to tangible employment results by facilitating individuals to get new jobs [21,22].

Furthermore, a total mediation of PE in the relationship between POS and employment status was also found. Since youth's perceptions were driven by a positive psychological state, they felt confident in their possibilities of getting a job, and this perception, in turn, increased the probability of this actually happening. As such, POS may represent a personal disposition related to the way individuals handle challenges, such as getting a job, perceiving themselves as capable (through enhancing PE), and motivating themselves to adapt their knowledge and skills so as to become employed [25,49]. This finding contributes to extending the literature on POS and its documented influence within the work domain $[30,65,68]$. Also, by accounting for the outcomes of alternative models (partial mediation), this study demonstrated that PE is the elective way through which POS is related to actual employment status.

Finally, this study also highlighted the moderation role of perceived support provided by employment agencies in the relationship between POS and PE. Results from path analysis revealed a nonsignificant direct relationship between perceived support from employment agencies and PE, while moderation analysis suggested that being supported exerted an amplification mechanism in the relationship between POS and PE. After all, employment agencies may provide youth with support in profiling and concrete employment opportunities (e.g., traineeship) within the Youth Guarantee program, helping to translate POS into PE. This finding is coherent with the moderation role assigned to contextual elements by the literature [103-105] and empirically proves the moderation role of context in determining PE suggested by Vanhercke et al. [15]. Moreover, this result extends the research on employment agencies' activities concerning the unemployed, providing unemployed youth with greater opportunities to be effectively re-employed [20,85]. Perceived support provided by the agency allows unemployed youth to maximize their opportunity to finding a job. However, taken in isolation, it does not represent a sufficient condition for elevating a participant's employability.

All in all, this study contributed to the understanding of how personal and contextual factors influence NEETs' perceived employability, and in turn, employment status. 


\subsection{Limitations and Future Research}

This study has some limitations that should be taken into account. One such limitation derives from the cross-sectional nature of this research. A longitudinal design, which provides temporal separation between antecedents, PE, and employment status, could have been useful in determining the direction of the influence between variables and should certainly be an objective of future research.

Another limitation stems from the lack of an explanation on how PE operatively brings youth to get a job after the Youth Guarantee program. Research on this topic has already shown that PE may lead to different types of job search strategies and behaviors among unemployed adults $[19,20]$, although further exploration of these findings still needs to be corroborated in the specific target of this study.

Furthermore, we focused on a dichotomous indicator of employment status, which did not provide information concerning the type of employment gained or the job attitudes developed by youth while engaging in the job they got. In this regard, previous research in organizational contexts has shown that PE is positively related with outcomes such as career success [27], job and life satisfaction [24,106], and affective commitment [100] and negatively related with emotional exhaustion and turnover intention [107]. Again, future research should go beyond the dichotomy of unemployment/employment, considering a broader set of objective and subjective quality of work indicators (such as income, career success, working hours, and job and life satisfaction).

Moreover, this study investigated the support provided by employment agencies as a perceived contextual factor. Future research should also account for the perceived support provided by the public employment offices, which, though these offices have a limited range of actions compared to the agencies, may provide an additional contribution in understanding the relationship between POS and PE.

Finally, another issue could be related to the generalizability of our results. Indeed, the label NEET comprises different categories of unemployed youth that may have different difficulties and motivation to enter the labor market $[7,8]$. Specifically, our sample focused on Youth Guarantee applicants who actively requested to participate in this program. Therefore, NEETs who are at a higher risk of social and work exclusion were likely not included in our study, since they are so disenchanted about finding a job that they do not even participate in programs such as Youth Guarantee. Future studies could be specifically designed to involve different categories of NEET, even those less engaged in finding a job.

\subsection{Practical Implications}

From a practical standpoint, this study highlights the relevance of POS and its interplay with perceived support from employment agencies in fostering PE and, in turn, objective employment status. POS has been conceived of as a basic predisposition, and genetic studies have pointed out that inheritance significantly contributes to determining the average set-point of individuals' POS [28]. Even though the contribution of life experiences and environmental opportunities should not be underestimated, POS represents a "potential" rather than an unchangeable legacy [108]. Therefore, the main practical implication from the present results lies in designing specific interventions aiming to strengthen youths' positive views about themselves, their lives, and their futures. To this end, previous studies have recommended paying individualized attention to the ways unemployed individuals cognitively and emotively appraise the labor market [20,77]. Specifically, in order to increase POS, cognitive restructuring of how youth approach the labor market should be utilized. POS could be increased through cognitive restructuring techniques such as rational-emotion behavior therapy (REBT) [109-111] and verbal self-guidance (VSG) [112] combined with goal-setting interventions [113]. Therefore, employment services should also fulfill a counseling function and be equipped with both work/organizational and clinical psychologists able to identify and develop personal resources through targeted interventions. 
Furthermore, given the role of perceived support from agencies in amplifying the relationship between POS and PE, the main challenge for agencies consists in capitalizing on their actions and moving beyond the practical role (i.e., profiling, finding job opportunities) that they have had to date. At the same time, employment offices should also be empowered to go beyond their role in managing administrative practices by offering concrete help in job search activities and providing tailored pathways, devoting time to understanding participant needs, in order to continuously guide and support individuals in this delicate transition from unemployment to employment.

On the other hand, the importance of personal variables on employment outcomes does not reduce the responsibility of organizations in creating more favorable hiring opportunities and actively participating in and supporting active labor market policy measures, such as Youth Guarantee, especially in a country that has one of the highest youth unemployment rates in Europe [82].

Finally, from a broader point of view, policy makers could pay more attention to the contextual resources available in different contexts (employment agencies, number of professionals, job opportunities) to provide targeted actions and economic resources in line with the specific needs of the social and economic environment. On the other hand, institutions and public employment agencies should be aware of the psychological factors that impact employment outcomes. Therefore, agencies should provide specific training programs to make employment professionals able to manage the psychological dimensions that contribute to searching for and obtaining employment.

This combined range of actions may, in line with the psychology of sustainability and sustainable development [12,13], improve the employment opportunities and quality of life of young people and communities.

Author Contributions: Conceptualization, C.C., L.B. and G.V.C.; methodology, G.A.; formal analysis, P.M.; investigation, C.C., L.B., G.V.C.; resources, L.V.; data curation, P.M.; writing—original draft preparation, P.M.; writing - review and editing, C.C. and G.A.; visualization, P.M.; supervision, C.C., L.B. and G.A.; project administration, L.B. and L.V. All authors have read and agreed to the published version of the manuscript.

Funding: This research received no external funding.

Institutional Review Board Statement: The study was conducted according to the guidelines of the Declaration of Helsinki and to the guidelines for personal data treatment defined by the General Data Protection Regulation (GDPR) and Italian privacy law (Law Decree DL-196/2003 and at. 89 of EU REGULATION 2016/679).

Informed Consent Statement: Informed consent was obtained from all subjects involved in the study.

Data Availability Statement: The data that support the findings of this study are available from the corresponding author, C.C., upon reasonable request.

Conflicts of Interest: The authors declare no conflict of interest.

\section{References}

1. Malo, M.A.; Mìnguez, M. European Youth Labour Markets; Springer: Cham, Switzerland, 2018.

2. Dietrich, H. Youth unemployment in the period 2001-2010 and the European crisis-looking at the empirical evidence. Transf. Eur. Rev. Labour Res. 2013, 19, 305-324. [CrossRef]

3. Bell, D.N.; Blanchflower, D.G. Young people and the Great Recession. Oxf. Rev. Econ. Pol. 2011, 27, 241-267. [CrossRef]

4. European Parliament. Covid-19: How the EU Fights Youth Unemployment. 2020. Available online: https://www.europarl. europa.eu/news/en/headlines/society/20200709STO83004/covid-19-how-the-eu-fights-youth-unemployment (accessed on 7 November 2020).

5. Eurostat. Unemployment Statistics and Beyond. 2020. Available online: https://ec.europa.eu/eurostat/statistics-explained/ index.php?title=Unemployment_statistics_and_beyond (accessed on 7 November 2020).

6. European Commission. The Youth Guarantee. 2020. Available online: https://ec.europa.eu/social/main.jsp?catId=1079\&langId= en (accessed on 7 November 2020).

7. Yates, S.; Payne, M. Not so NEET? A critique of the use of 'NEET' in setting targets for interventions with young people. J. Youth Stud. 2006, 9, 329-344. [CrossRef] 
8. Bynner, J.; Parsons, S. Social exclusion and the transition from school to work: The case of young people not in education, employment, or training (NEET). J. Vocat. Behav. 2002, 60, 289-309. [CrossRef]

9. Boeren, E.; Mackie, A.; Riddell, S. Employability pathways for young adults: Lived experiences of learners and practitioners in Youth Guarantee programmes. Int. J. Lifelong Educ. 2020, 39, 119-131. [CrossRef]

10. Allegretto, S.A. US youth: A lost generation in the making? Intereconomics 2013, 48, 323-324. [CrossRef]

11. Tamesberger, D.; Bacher, J. COVID-19 Crisis: How to Avoid a 'Lost Generation'. Intereconomics 2020, 55, 232-238. [CrossRef]

12. Di Fabio, A. The psychology of sustainability and sustainable development for well-being in organizations. Front. Psychol. 2017, 8, 1534. [CrossRef]

13. Di Fabio, A.; Rosen, M.A. Opening the Black Box of Psychological Processes in the Science of Sustainable Development: A new frontier. Eur. J. Sustain. Dev. Res. 2018, 2, 47. [CrossRef]

14. Manuti, A.; Giancaspro, M.L. People Make the Difference: An Explorative Study on the Relationship between Organizational Practices, Employees' Resources, and Organizational Behavior Enhancing the Psychology of Sustainability and Sustainable Development. Sustainability 2019, 11, 1499. [CrossRef]

15. Vanhercke, D.; De Cuyper, N.; Peeters, E.; De Witte, H. Defining perceived employability: A psychological approach. Pers. Rev. 2014, 43, 592-605. [CrossRef]

16. Berntson, E.; Marklund, S. The relationship between perceived employability and subsequent health. Work Stress 2007, 21, 279-292. [CrossRef]

17. Roskies, E.; Louis-Guerin, C. Job insecurity in managers: Antecedents and consequences. J. Organ. Behav. 1990, 11, 345-359. [CrossRef]

18. De Witte, H.; De Cuyper, N. Job insecurity and employability. In Wiley Encyclopedia of Management; Wiley: Hoboken, NJ, USA, 2015; Volume 5, pp. 1-3. [CrossRef]

19. Chen, D.J.; Lim, V.K. Strength in adversity: The influence of psychological capital on job search. J. Organ. Behav. 2012, 33, 811-839. [CrossRef]

20. De Battisti, F.; Gilardi, S.; Guglielmetti, C.; Siletti, E. Perceived employability and reemployment: Do job search strategies and psychological distress matter? J. Occup. Organ. Psychol. 2016, 89, 813-833. [CrossRef]

21. Knabe, A.; Rätzel, S. Better an insecure job than no job at all? Unemployment, job insecurity and subjective wellbeing. Econ. Bull. 2010, 30, 2486-2494.

22. Brouwer, S.; Bakker, R.H.; Schellekens, J.M.H. Predictors for re-employment success in newly unemployed: A prospective cohort study. J. Vocat. Behav. 2015, 89, 32-38. [CrossRef]

23. Berntson, E.; Näswall, K.; Sverke, M. Investigating the relationship between employability and self-efficacy: A cross-lagged analysis. Eur. J. Work Organ. Psychol. 2008, 17, 413-425. [CrossRef]

24. De Cuyper, N.; Bernhard-Oettel, C.; Berntson, E.; De Witte, H.; Alarco, B. Employability and employees' well-being: Mediation by job insecurity. Appl. Psychol. 2008, 57, 488-509. [CrossRef]

25. Fugate, M.; Kinicki, A.J.; Ashforth, B.E. Employability: A psycho-social construct, its dimensions, and applications. J. Vocat. Behav. 2004, 65, 14-38. [CrossRef]

26. Kirves, K.; Kinnunen, U.; De Cuyper, N. Contract type, perceived mobility and optimism as antecedents of perceived employability. Econ. Ind. Democr. 2014, 35, 435-453. [CrossRef]

27. McArdle, S.; Waters, L.; Briscoe, J.P.; Hall, D.T.T. Employability during unemployment: Adaptability, career identity and human and social capital. J. Vocat. Behav. 2007, 71, 247-264. [CrossRef]

28. Caprara, G.V.; Fagnani, C.; Alessandri, G.; Steca, P.; Gigantesco, A.; Sforza, L.L.C.; Stazi, M.A. Human optimal functioning: The genetics of positive orientation towards self, life, and the future. Behav. Genet. 2009, 39, 277-284. [CrossRef] [PubMed]

29. Caprara, G.V.; Steca, P.; Alessandri, G.; Abela, J.R.; McWhinnie, C.M. Positive orientation: Explorations on what is common to life satisfaction, self-esteem, and optimism. Epidemiol. Psichiatr. Soc. 2010, 19, 63-71. [CrossRef] [PubMed]

30. Alessandri, G.; Vecchione, M.; Tisak, J.; Deiana, G.; Caria, S.; Caprara, G.V. The utility of positive orientation in predicting job performance and organisational citizenship behaviors. Appl. Psychol. 2012, 61, 669-698. [CrossRef]

31. Hobfoll, S.E. Conservation of resources: A new attempt at conceptualizing stress. Am. Psychol. 1989, 44, 513-524. [CrossRef]

32. Hobfoll, S.E. Stress, Culture and Community. The Psychology and Philosophy of Stress; Plenum: New York, NY, USA, 1998.

33. Rothwell, A.; Jewell, S.; Hardie, M. Self-perceived employability: Investigating the responses of post-graduate students. J. Vocat. Behav. 2009, 75, 152-161. [CrossRef]

34. De Grip, A.; van Loo, J.; Sanders, J. The industry employability index: Taking account of supply and demand characteristics. Int. Labour Rev. 2004, 143, 211-233. [CrossRef]

35. Gazier, B. Employability—Definitions and trends. In Employability: Concepts and Policies; Gazier, B., Ed.; European Employment Observatory: Berlin, Germany, 1998; pp. 37-71.

36. Hillage, J.; Pollard, E. Employability: Developing a Framework for Policy Analysis; Institute for Employment Studies: London, UK, 1998.

37. McQuaid, R.W.; Lindsay, C. The concept of employability. Urban Stud. 2005, 42, 197-219. [CrossRef]

38. Guilbert, L.; Bernaud, J.L.; Gouvernet, B.; Rossier, J. Employability: Review and research prospects. Int. J. Educ. Vocat. Guid. 2016, 16, 69-89. [CrossRef] 
39. Fugate, M.; Kinicki, A.J. A dispositional approach to employability: Development of a measure and test of implications for employee reactions to organizational change. J. Occup. Organ. Psychol. 2008, 81, 503-527. [CrossRef]

40. Lo Presti, A.; Pluviano, S. Looking for a route in turbulent waters: Employability as a compass for career success. Organ. Psychol. Rev. 2016, 6, 192-211. [CrossRef]

41. Van der Heijde, C.M.; Van der Heijden, B.I.J.M. A competence-based and multidimensional operationalization and measurement of employability. Hum. Resour. Manag. 2006, 45, 449-476. [CrossRef]

42. Van der Heijden, B.I.; de Lange, A.H.; Demerouti, E.; Van der Heijde, C.M. Age effects on the employability-career success relationship. J. Vocat. Behav. 2009, 74, 156-164. [CrossRef]

43. Coetzee, M. Psychological career resources of working adults: A South African survey. S. Afr. J. Ind. Psychol. 2008, $34,32-41$. [CrossRef]

44. Rothwell, A.; Herbert, I.; Rothwell, F. Self-perceived employability: Construction and initial validation of a scale for university students. J. Vocat. Behav. 2008, 73, 1-12. [CrossRef]

45. Forrier, A.; Sels, L. The concept employability: A complex mosaic. Int. J. Hum. Res. Dev. Manag. 2003, 3, 102-124. [CrossRef]

46. De Cuyper, N.; Van der Heijden, B.I.; De Witte, H. Associations between perceived employability, employee well-being, and its contribution to organizational success: A matter of psychological contracts? Int. J. Hum. Res. Manag. 2011, 22, 1486-1503. [CrossRef]

47. Rothwell, A.; Arnold, J. Self-perceived employability: Development and validation of a scale. Pers. Rev. 2007, 36, 23-41. [CrossRef]

48. De Cuyper, N.; Raeder, S.; Van der Heijden, B.I.J.M.; Wittekind, A. The association between workers' employability and burnout in a reorganization context: Longitudinal evidence building upon the conservation of resources theory. J. Occup. Health Psychol. 2012, 17, 162-174. [CrossRef]

49. Forrier, A.; Sels, L.; Stynen, D. Career mobility at the intersection between agent and structure: A conceptual model. J. Occup. Organ. Psychol. 2009, 82, 739-759. [CrossRef]

50. Wanberg, C.R.; Zhu, J.; Van Hooft, E.A. The job search grind: Perceived progress, self-reactions, and self-regulation of search effort. Acad. Manag. J. 2010, 53, 788-807. [CrossRef]

51. Westaby, J.D.; Braithwaite, K.N. Specific factors underlying reemployment self-efficacy. J. Appl. Behav. Sci. 2003, 39, 415-437. [CrossRef]

52. Katz, D.; Kahn, R.L. The Social Psychology of Organizations; Wiley: Hoboken, NJ, USA, 1978; Volume 2.

53. Wittekind, A.; Raeder, S.; Grote, G. A longitudinal study of determinants of perceived employability. J. Organ. Behav. 2010, 31, 566-586. [CrossRef]

54. Wille, B.; De Fruyt, F.; Feys, M. Big Five Traits and Intrinsic Success in the New Career Era: A 15-Year Longitudinal Study on Employability and Work-Family Conflict. Appl. Psychol. 2013, 62, 124-156. [CrossRef]

55. Rodrigues, R.; Butler, C.L.; Guest, D. Antecedents of protean and boundaryless career orientations: The role of core selfevaluations, perceived employability and social capital. J. Vocat. Behav. 2019, 110, 1-11. [CrossRef]

56. Harter, S. The self. In Handbook of Child Psychology, 6th ed.; Eisenberg, N., Damon, W., Lerner, R.M., Eds.; John Wiley: Hoboken, NJ, USA, 2006; Volume 3, pp. 505-570.

57. Scheier, M.F.; Carver, C.S. Optimism, coping, and health: Assessment and implications of generalized outcome expectancies. Health Psychol. 1985, 4, 219-247. [CrossRef] [PubMed]

58. Scheier, M.F.; Carver, C.S. Effects of optimism on psychological and physical well-being: Theoretical overview and empirical update. Cogn. Ther. Res. 1992, 16, 201-228. [CrossRef]

59. Scheier, M.F.; Carver, C.S. Adapting to cancer: The importance of hope and purpose. In Psychosocial Interventions for Cancer; Baum, A., Andersen, B.L., Eds.; American Psychological Association: Washington, DC, USA, 2001; pp. 15-36.

60. Diener, E. Subjective well-being. Psychol. Bull. 1984, 95, 542-575. [CrossRef]

61. Organ, D.W. Organizational Citizenship Behavior: The Good Soldier Syndrome; Lexington Books: Lexington, MA, USA, 1988.

62. Digman, J.M. Personality structure: Emergence of the five-factor model. Annu. Rev. Psychol. 1990, 41, 417-440. [CrossRef]

63. Watson, D.; Clark, L.A.; Tellegen, A. Development and validation of brief measures of positive and negative affect: The PANAS scales. J. Pers. Soc. Psychol. 1988, 54, 1063-1070. [CrossRef] [PubMed]

64. Judge, T.A.; Erez, A.; Bono, J.E. The power of being positive: The relation between positive self-concept and job performance. Hum. Perform. 1998, 11, 167-187. [CrossRef]

65. Alessandri, G.; Borgogni, L.; Schaufeli, W.B.; Caprara, G.V.; Consiglio, C. From positive orientation to job performance: The role of work engagement and self-efficacy beliefs. J. Happiness Stud. 2015, 16, 767-788. [CrossRef]

66. Schaufeli, W.B.; Martinez, I.M.; Pinto, A.M.; Salanova, M.; Bakker, A.B. Burnout and engagement in university students: A cross-national study. J. Cross-Cult. Psychol. 2002, 33, 464-481. [CrossRef]

67. Laguna, M.; Alessandri, G.; Caprara, G.V. Personal goal realisation in entrepreneurs: A multilevel analysis of the role of affect and positive orientation. Appl. Psychol. 2016, 65, 587-604. [CrossRef]

68. Theodorou, A.; Violani, C.; Alessandri, G. Vivere senza un lavoro: Positività e salute psicofisica in un campione di disoccupati [Living without a job: Positivity and psychophysical health in a sample of unemployed people]. Giorn. Ital. Psicol. 2017, 44, 993-1006. [CrossRef]

69. Caprara, G.V.; Alessandri, G.; Eisenberg, N.; Kupfer, A.; Steca, P.; Caprara, M.G.; Yamaguchi, S.; Fukuzawa, A.; Abela, J. The Positivity Scale. Psychol. Assess. 2012, 24,701-712. [CrossRef] 
70. Antonovsky, A. Health, Stress and Coping; Jossey-Bass: San Francisco, CA, USA, 1979.

71. Silla, I.; De Cuyper, N.; Gracia, F.J.; Peiro, J.M.; De Witte, H. Job insecurity and well-being: Moderation by employability. J. Happiness Stud. 2009, 10, 739-751. [CrossRef]

72. Kinnunen, U.; Mäkikangas, A.; Mauno, S.; Siponen, K.; Nätti, J. Perceived employability: Investigating outcomes among involuntary and voluntary temporary employees compared to permanent employees. Career Dev. Int. 2011, 16, 140-160. [CrossRef]

73. Kirves, K.; De Cuyper, N.; Kinnunen, U.; Nätti, J. Perceived job insecurity and perceived employability in relation to temporary and permanent workers' psychological symptoms: A two samples study. Int. Arch. Occup. Environ. Health 2011, 84, 899-909. [CrossRef]

74. LoPresti, A.; Magrin, E.; Ingusci, E. Employability as a compass for career success: Development and initial validation of a new multidimensional measure. Int. J. Train. Dev. 2020, 24, 4-301. [CrossRef]

75. Forrier, A.; Verbruggen, M.; De Cuyper, N. Integrating different notions of employability in a dynamic chain: The relationship between job transitions, movement capital and perceived employability. J. Vocat. Behav. 2015, 89, 56-64. [CrossRef]

76. Cron, W.L.; Slocum Jr, J.W. The influence of career stages on salespeople's job attitudes, work perceptions, and performance. J. Mark. Res. 1986, 23, 119-129. [CrossRef]

77. Kanfer, R.; Wanberg, C.R.; Kantrowitz, T.M. Job search and employment: A personality-motivational analysis and meta-analytic review. J. Appl. Psychol. 2001, 86, 837-855. [CrossRef]

78. Wanberg, C.R. The individual experience of unemployment. Annu. Rev. Psychol. 2012, 63, 369-396. [CrossRef]

79. Hobfoll, S.E. Conservation of resource caravans and engaged settings. J. Occup. Organ. Psychol. 2011, 84, 116-122. [CrossRef]

80. Hobfoll, E.; Halbesleben, J.; Neveu, J.P.; Westman, M. Conservation of Resources in the Organizational Context: The Reality of Resources and Their Consequences. Annu. Rev. Organ. Psychol. 2018, 5, 103-128. [CrossRef]

81. Council of the European Union. Council Recommendation of 22 April 2013 on establishing a Youth Guarantee, 2013/C 120/01. Off. J. Eur. Union 2013, C 120,1-6.

82. ISTAT. Rapporto Annuale 2020: La Situazione del Paese (Annual Report 2020: The Situation of the Country). Available online: https:/ / www.istat.it/storage/rapporto-annuale/2020/Rapportoannuale2020.pdf (accessed on 2 February 2021).

83. Andrews, J.; Higson, H. Graduate employability, 'soft skills' versus 'hard' business knowledge: A European study. High. Educ. Eur. 2008, 33, 411-422. [CrossRef]

84. Bridgstock, R. The graduate attributes we've overlooked: Enhancing graduate employability through career management skills. High. Educ. Res. Dev. 2009, 28, 31-44. [CrossRef]

85. Liu, S.; Huang, J.L.; Wang, M. Effectiveness of job search interventions: A meta-analytic review. Psychol. Bull. 2014, 140, 1009-1041. [CrossRef]

86. Tofighi, D.; MacKinnon, D.P. RMediation: An R package for mediation analysis confidence intervals. Behav. Res. Methods 2011, 43, 692-700. [CrossRef] [PubMed]

87. Aiken, L.S.; West, S.G. Multiple Regression: Testing and Interpreting Interactions; Sage: Newbury Park, CA, USA, 1991.

88. Van der Heijden, B. Prerequisites to guarantee life-long employability. Pers. Rev. 2002, 31, 44-61. [CrossRef]

89. Muthén, L.K.; Muthén, B.O. Mplus User's Guide, 8th ed.; Muthen \& Muthen: Los Angeles, CA, USA, 2017.

90. Muthén, B.; du Toit, S.H.C.; Spisic, D. Robust Inference Using Weighted Least Squares and Quadratic Estimating Equations in Latent Variable Modeling with Categorical and Continuous Outcomes. College of Education, UCLA: Los Angeles, CA, USA, Unpublished work; Available online: http://gseis.ucla.edu/faculty/muthen/articles/Article_075.pdf (accessed on 10 December 2020).

91. DiStefano, C.; Liu, J.; Jiang, N.; Shi, D. Examination of the weighted root mean square residual: Evidence for trustworthiness? Struct. Equ. Model. Multidiscip. J. 2018, 25, 453-466. [CrossRef]

92. Li, C.H. The Performance of MLR, USLMV, and WLSMV Estimation in Structural Regression Models with Ordinal Variables; Michigan State University: Michigan, MI, USA, 2014.

93. Finney, S.J.; DiStefano, C. Nonnormal and categorical data in structural equation modeling. In Structural Equation Modeling: A Second Course, 2nd ed.; Hancock, G.R., Mueller, R.O., Eds.; Information Age Publishing: Charlotte, NC, USA, 2013 ; pp. 439-492.

94. Bentler, P.M. Comparative fit indexes in structural models. Psychol. Bull. 1990, 107, 238-246. [CrossRef] [PubMed]

95. Browne, M.W.; Cudek, R. Alternative ways of assessing model fit. In Testing Structural Equation Models; Bollen, K.A., Long, J.S., Eds.; Sage: Newbury Park, CA, USA, 1993; pp. 136-162.

96. Hu, L.T.; Bentler, P.M. Fit indices in covariance structure modeling: Sensitivity to underparameterized model misspecification. Psychol. Methods 1998, 3, 424-453. [CrossRef]

97. Perinelli, E.; Alessandri, G.; Vecchione, M.; Mancini, D. A comprehensive analysis of the psychometric properties of the contingencies of self-worth scale (CSWS). Curr. Psychol. 2020, 1021, 1-16. [CrossRef]

98. Burnham, K.P.; Anderson, D.R. Multimodel inference: Understanding AIC and BIC in model selection. Sociol. Methods Res. 2004, 33, 261-304. [CrossRef]

99. McKee-Ryan, F.; Song, Z.; Wanberg, C.R.; Kinicki, A.J. Psychological and Physical Well-Being During Unemployment: A Meta-Analytic Study. J. Appl. Psychol. 2005, 90, 53-76. [CrossRef] [PubMed]

100. Diener, E.; Napa-Scollon, C.K.; Oishi, S.; Dzokoto, V.; Suh, E.M. Positivity and the construction of life satisfaction judgments: Global happiness is not the sum of its parts. J. Happiness Stud. 2000, 1, 159-176. [CrossRef] 
101. Caprara, M.; Di Giunta, L.; Caprara, G.V. Association of positivity with health problems in old age: Preliminary findings from Spanish middle class seniors. J. Happiness Stud. 2017, 18, 1339-1358. [CrossRef]

102. De Cuyper, N.; De Witte, H. Temporary employment and perceived employability: Mediation by impression management. J. Career Dev. 2010, 37, 635-652. [CrossRef]

103. Johns, G. The essential impact of context on organizational behavior. Acad. Manag. Rev. 2006, 31, 386-408. [CrossRef]

104. Johns, G. Reflections on the 2016 decade award: Incorporating context in organizational research. Acad. Manag. Rev. 2017, 42, 577-595. [CrossRef]

105. Kozlowski, S.W.J.; Klein, K.J. A multilevel approach to theory and research in organizations: Contextual, temporal, and emergent processes. In Multilevel Theory, Research, and Methods in Organizations: Foundations, Extensions, and New Directions; Klein, K.J., Kozlowski, S.W.J., Eds.; Jossey-Bass: Hoboken, NJ, USA, 2000; pp. 3-90.

106. De Cuyper, N.; Notelaers, G.; De Witte, H. Job insecurity and employability in fixed-term contractors, agency workers, and permanent workers: Associations with job satisfaction and affective organizational commitment. J. Occup. Health Psychol. 2009, 14, 193-205. [CrossRef]

107. Lu, C.Q.; Sun, J.W.; Du, D.Y. The relationships between employability, emotional exhaustion, and turnover intention: The moderation of perceived career opportunity. J. Career Dev. 2016, 43, 37-51. [CrossRef]

108. Caprara, G.V.; Alessandri, G.; Barbaranelli, C. Optimal functioning. Psychother. Psychosom. 2010, 79, 328-330. [CrossRef]

109. Ellis, A. Reason and Emotion in Psychotherapy; Lyle Stuart: New York, NY, USA, 1962.

110. Ellis, A. The biological basis of human irrationality. J. Individ. Psychol. 1976, 32, 145-168.

111. Ellis, A. Overcoming Resistance: Rational-Emotive Therapy with Difficult Clients; Springer: New York, NY, USA, 1985.

112. Millman, Z.; Latham, G.P. Increasing reemployment through training in verbal self-guidance. In Work Motivation in the Context of a Globalizing Economy; Erez, M., Kleinbeck, U., Thierry, H., Eds.; Lawrence Erlbaum: Mahwah, NJ, USA, 2001 ; pp. 87-97.

113. Brown, T.C.; Latham, G.P. The effect of training in verbal self-guidance on performance effectiveness in a MBA program. Can. J. Behav. Sci. 2006, 38, 1-11. [CrossRef] 